\title{
Management of Fertigation in Horticultural Crops through Automation with Electrotensiometers: Effect on the Productivity of Water and Nutrients
}

\author{
Juana I. Contreras *(D), Rafael Baeza, José G. López, Gema Cánovas and Francisca Alonso
}

Citation: Contreras, J.I.; Baeza, R.; López, J.G.; Cánovas, G.; Alonso, F. Management of Fertigation in Horticultural Crops through Automation with Electrotensiometers: Effect on the Productivity of Water and Nutrients. Sensors 2021, 21, 190. https://doi.org/10.3390/s21010190

Received: 4 December 2020 Accepted: 25 December 2020 Published: 30 December 2020

Publisher's Note: MDPI stays neutral with regard to jurisdictional clai$\mathrm{ms}$ in published maps and institutional affiliations.

Copyright: (C) 2020 by the authors. Licensee MDPI, Basel, Switzerland. This article is an open access article distributed under the terms and conditions of the Creative Commons Attribution (CC BY) license (https:// creativecommons.org/licenses/by/ $4.0 /)$.
Institute of Research and Training in Agriculture and Fishery (IFAPA), Junta of Andalucia, La Mojonera, 04630 Almería, Spain; rafaelj.baeza@juntadeandalucia.es (R.B.); jgabriel.lopez@juntadeandalucia.es (J.G.L.); gema.canovas@juntadeandalucia.es (G.C.); f.alonso@juntadeandalucia.es (F.A.)

* Correspondence: juanai.contreras@juntadeandalucia.es; Tel.: +34-950-156-453

\begin{abstract}
Water and nutrient requirements of horticultural crops are influenced by different factors such as: Type of crop, stage of development and production system. Although greenhouse horticultural crops are more efficient in the use of water and fertilizers compared to other production systems, it is necessary increase efficiency for which individualized fertigation strategies must be designed for each greenhouse. The automation of fertigation based on the level of soil moisture allows optimization of management. The objective of this work was to determine the influence of the activation command of fertigation with electrotensiometers and the characteristics of the greenhouse on the productivity of the crop and the efficiency of use of water and nutrients in a sweet pepper crop. The trial was developed in two greenhouses. Four treatments were studied, combination of who two-factor: Soil matric potential (SMP) $\left(\mathrm{SMP}_{-10}\right.$ : Automatic activation of irrigation to $-10 \mathrm{kPa}$ and SMP -20 : Automatic activation of irrigation to $-20 \mathrm{kPa})$ and greenhouse characteristics $\left(\mathrm{G}_{1}\right.$ and $G_{2}$ ). The nutritive solution applied was the same in all treatments. The yield and volume of water and nutrients applied were determined, calculating the productivity of the water (WP), as well as productivity the nutrients. The fertigation activation threshold of $-10 \mathrm{kPa}$ presented the best results, increasing the yield and conserving WP and nutrient productivity with respect to $-20 \mathrm{kPa}$ in both greenhouses. The automation of irrigation with electrotensiometers allowed the application of different volume of fertigation demanded by the crop in each greenhouse, equalizing the WP and nutrient productivity without producing drainage. The pepper crop in the greenhouse $\mathrm{G}_{1}$ presented greater vegetative development, higher yield and demanded a greater volume of fertigation than $\mathrm{G}_{2}$ regardless of the activation threshold. This was due to the fact that the soil matric potential after irrigation in greenhouse $G_{1}$ was closer to zero, being able to conclude that not only the soil matric potential threshold of irrigation activation has an influence on crop, but also the potential registered after irrigation. Soil matric potentials closer to zero are more productive.
\end{abstract}

Keywords: greenhouse; irrigation; activation threshold; water productivity; soil matric potential; drainage; biomass; harvest index

\section{Introduction}

In the current climate change scenario, the availability of water for human activities is expected to decrease [1]. Of these activities, agriculture is the one that consumes the most water, with irrigated agriculture accounting for $70 \%$ of freshwater extraction, and this percentage can reach $90 \%$ in some regions. Of the total water used, about $20 \%$ comes from groundwater sources (renewable or not), and this proportion is increasing rapidly, especially in dry areas [2]. Given this situation, with limited water resources, the use of drip irrigation systems is increasing throughout the world. This irrigation system can provide water to the plant frequently and directly in the root zone of the plant [3], being able to achieve a very high irrigation efficiency. Not only is the irrigation system important, irrigation 
management must also be efficient to minimize the possible environmental impact derived from it, as well as promote the sustainable use of resources [4,5]. In cultivation systems where drip irrigation systems are used, the use of fertigation for the supply of nutrients has become widespread, so in these systems soil is not irrigated, it is fertigated.

Horticultural crops have different fertigation needs depending on factors such as: Type of crop, stage of development and production system. Despite of the fact that greenhouse horticultural crops are very efficient in the use of water and fertilizers compared to other production systems, it is necessary to increase efficiency, for which individual fertigation strategies must be designed for each crop and each situation.

The water and nutritional needs of greenhouse horticultural crops have been extensively studied. The works that determine the water needs are mainly focused on the predictive calculation of crop evapotranspiration (ETc) with average climatic data or real-time data [6-8]. However, for the same crop, the different varieties show different vegetative development (some are more vegetative than others). Furthermore, the growing conditions of the crop can affect the vegetative development of the crop. For this reason, the most recent research has been directed towards the dynamic determination of the crop coefficient $\left(\mathrm{K}_{\mathrm{c}}\right)$ in situ, using photo digitization systems that monitor plant growth [9], and towards the use of humidity sensors of the soil that allow irrigation on demand [4].

Regarding fertigation, most of the research focuses on determining standard nutrient solutions for each crop and stage [10], as well as determining the extraction and absorption curves of the different crops [11-14]. As in irrigation, the different vegetative development generates, for the same crop, depending on the variety and growing conditions, different nutritional needs. Hence, the most recent investigations focus on the dynamic determination of these needs in situ through: Use of optical sensors to determine the nitrogen content in crops [15,16], use of systems for monitoring the level of nutrients in the soil solution $[13,17,18]$ and development and adaptation of different simulation models of nutrient requirements $[19,20]$.

The cultivation system has a great influence on the consumption of water and fertilizers [20-22]. Within the greenhouse cultivation system there are several factors that determine and modify the consumption of water and fertilizers, since they modify the environmental conditions in which they develop, such as: Greenhouse structure, ventilation and type of soil. [23-26]. Not only do the structural factors have influence, but so do the cultivation techniques such as pruning, phytosanitary treatments, since they modify the index of leaf area and the biomass of the cultivation.

Since the late 1980s, great advances in electronics and information technologies have led to significant progress in the development, availability, and application of sensors for use in irrigation scheduling and automation. Electrotensiometers are soil matric potential (SMP) sensors for a continuous control of water application by a computer. The automation of irrigation using electrotensiometers can be a viable option at the farm level that, among other advantages, offers the possibility of watering according to the individual characteristics of greenhouses and crops and can provide a more precise adjustment of the irrigation frequency to the crop needs at every moment of the cycle, minimizing losses due to drainage to deeper layers. In addition, limiting drainage, also is preventing nutrient leaching that can cause contamination of aquifers. However, for automatic irrigation control based on a value of the soil matric potential to be effective, it is essential to establish an adequate value from which irrigation begins. This threshold value depends on the crop species, its development stage, evaporative conditions and soil texture [27].

Many of the studies carried out for a specific species show a wide range of threshold values of soil matric potential, which suggests, as pointed out by Thompson et al. [28] the influence of site-specific factors. Therefore, it is very important to establish the appropriate value of threshold values of soil matric potential for each crop and specific development condition that optimize production and efficiency in the use of water and nutrients $[4,29,30]$.

The pepper is one of the most important horticultural crops (Capsicum anuum L.) for greenhouse production. Specifically, in Spain, its production is concentrated on the 
Mediterranean coast of Andalusia, highlighting Almería as the main growing area with more than 11,000 ha and an annual production of 845,595 tons [31].

The objective of this work was to determine the influence of the fertigation activation command with electrotensiometers and the characteristics of the greenhouse on the water and nutrients productivity in a pepper crop.

\section{Materials and Methods}

\subsection{Experimental Site}

The trial was carried out at the IFAPA La Mojonera Center, Almería, in two multitunnel greenhouses with a semi-elliptic curved roof of the same surface $\left(900 \mathrm{~m}^{2}\right)$ and orientation (east-west), with a passive climate, with a metal structure, plastic polyethylene cover and windows lateral and zenithal. In both greenhouses, the cultivation system was soil with addition of layer of sand about $5 \mathrm{~cm}$, characteristic of intensive horticultural crops in the Southeast of the Peninsula [32].

\subsection{Experimental Design and Cropping Systems}

The experimental design used balanced incomplete block 2 by 2 factorial design with eight replicates (four per greenhouse), resulting in the combination of the two factors studied in the four treatments tested. Each greenhouse was divided into 4 blocks and in each one of them the treatments were placed randomly distributed, resulting in 16 experimental plots per greenhouse (Figure 1). A single plot measured $12 \mathrm{~m}$ by $4 \mathrm{~m}$.
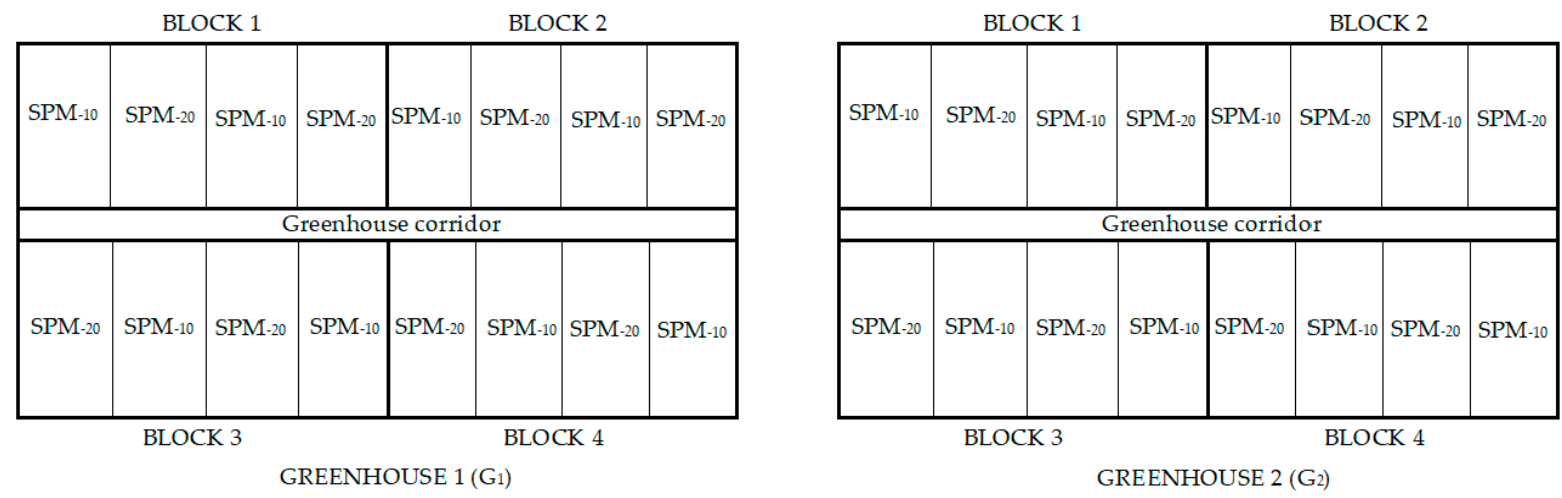

Figure 1. Experimental design.

The factors studied were: SMP and greenhouse $(G)$.

Two levels of SMP have been established, $\mathrm{SMP}_{-10}$ : Automatic activation of irrigation through an electronic tensiometer when the level of SMP was $-10 \mathrm{kPa}$, and SMP -20 : Automatic activation of irrigation through an electronic tensiometer when the level of SMP was $-20 \mathrm{kPa}$. The timing of irrigation was constant throughout the cycle (being $30 \mathrm{~min}$ ) and the same for two levels of SMP. The frequency of irrigation depended on the value of the SMP established in each treatment. In a previous experiment, we established three levels of soil matric potential $-10 \mathrm{kPa},-20 \mathrm{kPa}$ and $-30 \mathrm{kPa}$, as well as a fourth treatment that received the irrigation calculated with the irrigation scheduling based on crop evapotranspiration. Under the development conditions, the soil matric tension threshold of $-20 \mathrm{kPa}$ was the one that had shown the best results considering the water and nutrient productivity criteria, but $-10 \mathrm{kPa}$ was the highest fruit yield [33]. For this reason, in this experiment we have studied these two levels.

The total volumes of irrigation applied were different in each treatment, since irrigation was managed by the threshold level of soil matric potential established for each treatment. What remained constant in all treatments was the irrigation activation period, which was from 10:00 a.m. to 6:00 p.m. in winter and from 8:00 a.m. to 8:00 p.m. in spring. A $2 \mathrm{~h}$ pause was also established after each irrigation to ensure the correct response for the acquisition of tensiometric data. 
Two different greenhouses have been studied: $G_{1}$ and $G_{2}$. The differences between the greenhouses were greenhouse height, size and the type of lateral and zenith windows, and the properties of the soil. Greenhouse $\mathrm{G}_{1}$ was more height than $\mathrm{G}_{2}(4.2 \mathrm{~m}$ of the gutter height and the total ridge height was $6 \mathrm{~m}$ ) and more height lateral windows $(1.7 \mathrm{~m})$, and had zenith windows at the top of a quarter arch (Figure 2) and soil with a clay loam texture (Table 1). Greenhouse $G_{2}$ had zenith windows at the top of a half arch with an opening in the gutter (Figure 2), $3.6 \mathrm{~m}$ of the height to gutter and the total height to ridge was $5.4 \mathrm{~m}$, height lateral windows of $1.25 \mathrm{~m}$ and soil with a clay texture (Table 1).

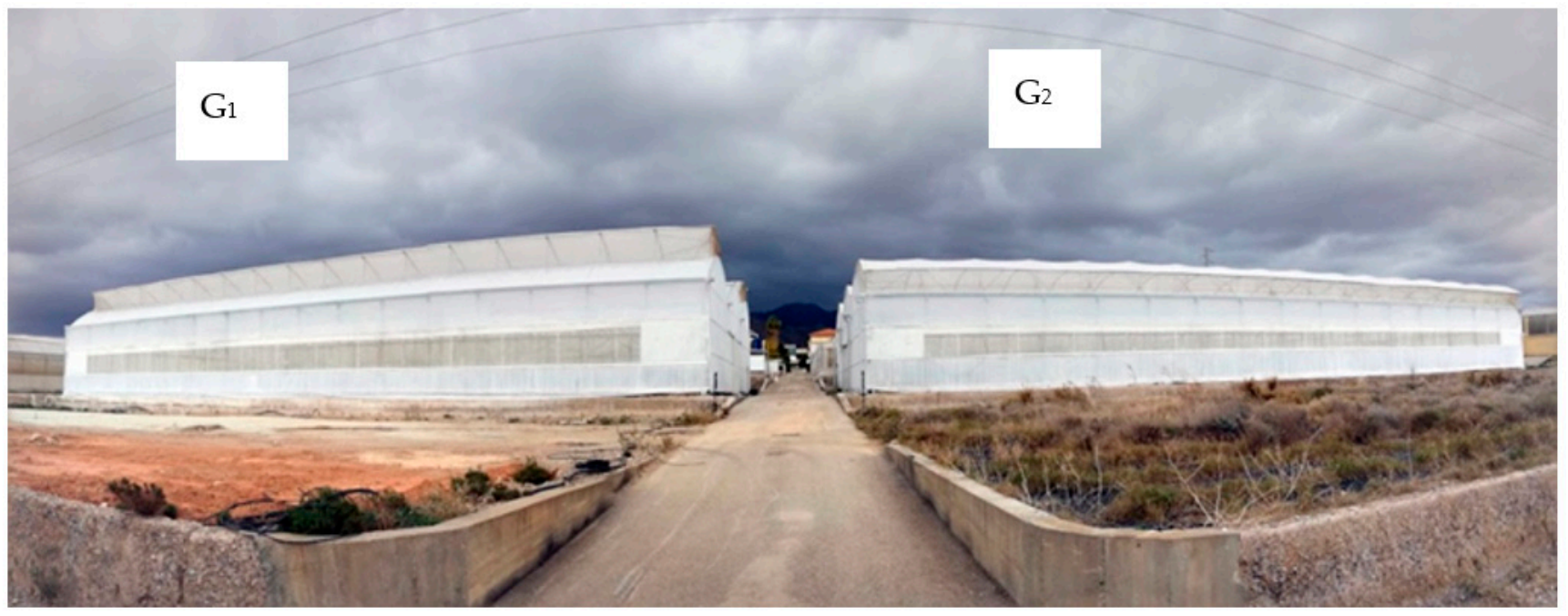

Figure 2. Greenhouse studied.

Table 1. Physical and chemical properties of the soil. Electrical conductivity (EC), $\mathrm{pH}$ and sodium adsorption ratio (SAR) were determined in the water extract from saturated soil paste. Organic matter $(\mathrm{OM})$ and exchangeable cations.

\begin{tabular}{|c|c|c|c|c|c|c|c|c|c|c|c|c|}
\hline & \multirow[b]{2}{*}{ Texture } & \multirow[b]{2}{*}{ Sand } & \multirow[b]{2}{*}{ Silt } & \multirow[b]{2}{*}{ Clay } & \multirow[b]{2}{*}{ EC } & \multirow[b]{2}{*}{$\mathrm{pH}$} & \multirow[b]{2}{*}{ SAR $^{a}$} & \multirow[b]{2}{*}{$\mathrm{OM}^{\mathrm{b}}$} & \multicolumn{4}{|c|}{ Exchangeable Cations } \\
\hline & & & & & & & & & $\mathrm{Na}$ & $\mathbf{K}$ & $\mathrm{Ca}$ & $\mathrm{Mg}$ \\
\hline & & & $\%$ & & $\mathrm{dS} \mathrm{m}^{-1}$ & & & $\%$ & \multicolumn{4}{|c|}{ meq/100 g } \\
\hline $\mathrm{G}_{1}$ & clay loam & 22 & 46 & 32 & 4.42 & 9.0 & 2.1 & 0.41 & 0.0 & 2.6 & 3.7 & 2.1 \\
\hline $\mathrm{G}_{2}$ & clay & 34 & 18 & 48 & 2.97 & 8.7 & 2.8 & 0.78 & 0.1 & 4.3 & 5.4 & 4.2 \\
\hline
\end{tabular}

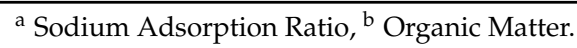

To determine the physical-chemical parameters in the soil twenty random sample points of each replication were selected to be taken and the samples of soil were mixed to achieve a representative soil sample per replication. The samples of soil were dried in a forced air oven (MEMMERT Model 800) at $50{ }^{\circ} \mathrm{C}$ for $48 \mathrm{~h}$ and then were gridded and screened $(2 \mathrm{~mm})$.

Texture of soils (clay, silt and sand percentages) was determined by Bouyoucoshydrometer analysis [34]. $\mathrm{pH}$ and electrical conductivity (EC) were determined in the saturated extract by pHmeter (model MicropH 2002 Crison, Hach Large Spain S.L.U., Barcelona, Spain) and conductivity meter (model GLP31 Crison, Hach Large Spain S.L.U., Barcelona, Spain), respectively. Sodium adsorption ratio (SAR) was determined in the water extract from saturated soil paste. Organic matter was determined using the Walkley-Black method [35].

The interpretation of the soil-water characteristic curves (SWCC) for each soil are show in Table 2. SWCC describes the amount of water retained in a soil (expressed as volume water content, $\theta \mathrm{v}$ ) under equilibrium at a given matric potential. The model used to predict such relationship was Van Genuchten [36]. An SWCC is an important hydraulic property, related to size and connectedness of pore spaces, hence strongly affected by soil texture and 
structure, and by other constituents, including organic matter. The soil of the $\mathrm{G}_{1}$ greenhouse has a higher $\theta v$ than the soil of the $G_{2}$ greenhouse for the same SMP level (Table 2).

Table 2. Interpretation of the soil-water characteristic curves (SWCC) for each soil.

\begin{tabular}{ccc}
\hline SMP (-kPa) & \multicolumn{3}{c}{$\boldsymbol{\theta \mathbf { v }} \mathbf{( \% )}$} \\
\hline & $\mathbf{G}_{\mathbf{1}}$ & $\mathbf{G}_{\mathbf{2}}$ \\
\hline 0 & 25.46 & 22.88 \\
10 & 23.13 & 16.56 \\
20 & 21.64 & 14.61 \\
30 & 20.59 & 13.50 \\
33 & 20.35 & 13.26 \\
40 & 19.86 & 12.79 \\
50 & 19.24 & 12.23 \\
100 & 17.39 & 10.66 \\
500 & 13.51 & 7.71 \\
1000 & 12.09 & 6.71 \\
1500 & 11.31 & 6.17 \\
\hline
\end{tabular}

Irrigation was applied by drip irrigation. Pressure-compensating and self-closing drippers were employed (PCJ Dripper-Netafim ${ }^{\circledR}$ ). The flow rate of the emitters was $3 \mathrm{~L} \mathrm{~h}^{-1}$ and two emitters per square meter were installed (spaced at $0.5 \mathrm{~m}$ in the drip line and $1 \mathrm{~m}$ between lines).

The concentration of the nutrient solution applied was the same for all treatments and remained constant throughout the cultivation cycle, being in mM: 12 of $\mathrm{NO}_{3}{ }^{-}, 1.5$ of $\mathrm{H}_{2} \mathrm{PO}_{4}{ }^{-}, 1.5$ of $\mathrm{SO}_{4}{ }^{2-}, 6.0$ of $\mathrm{K}^{+}, 5.0$ of $\mathrm{Ca}^{2+}$ and 2.0 of $\mathrm{Mg}^{2+}$.

Pepper plants (Capsicum anuum L. type Lamuyo cv. Mazo) were transplanted on 5 September 2018 with a plant density of 2 plants $\mathrm{m}^{-2}$ and the cycle ended on 23 April 2019.

\subsection{Measurements}

Climatic parameters in greenhouses: Air temperature and air relative humidity inside the two greenhouses were measured. The measurements were recorded every $30 \mathrm{~min}$ during $24 \mathrm{~h}$ a day. Daily mean vapor pressure deficit (VPD) was calculated for each greenhouse.

Soil matric potential was measured in the most representative area of the plant roots. For this, 32 electrotensiometers (Irrometer Co., Inc., Riverside, CA, USA) were installed, 8 per treatment. The electrotensiometers were placed $15 \mathrm{~cm}$ deep and $15 \mathrm{~cm}$ from the base of the plant. Soil matric tension measurements were automatically recorded by a Red Himarcan ${ }^{\circledR}$ System control device.

Soil drainage volume was determined for each treatment. For this, each greenhouse was equipped with 16 drainage lysimeters (one for treatment and replication) of $1 \mathrm{~m}^{2}$ of surface, installed at a depth of $50 \mathrm{~cm}$, discounting the upper layer of sand. The volume of water drained was measured daily throughout the experiment.

Irrigation water and nutrients applied were measured by installing three volumetric water meters, model M120 (Elster, Iberconta S.A., Gipuzkoa, Spain), one for treatment, also was corroborated with the registration number of irrigations performed and the volume applied in each irrigation. The concentration of nutrients $\left(\mathrm{NO}_{3}{ }^{-}, \mathrm{P}, \mathrm{K}^{+}, \mathrm{Ca}^{2+}\right.$ and $\left.\mathrm{Mg}^{2+}\right)$ in the applied nutrient solution was analyzed in the laboratory weekly. The samples were collected at the outlet by the dropper, placing a carafe that collected the volume of fertigation applied weekly in each treatment.

Yield of the pepper crop was evaluated by manually harvesting the red fruits. The production of 48 plants was controlled per replication and treatment, resulting in a total of 384 plants per treatment. The harvest period began on 9 January 2019 and ended on 23 April 2019, with a total of 5 harvests. The weight and number of marketable and 
unmarketable fruits were counted. The marketable fruits were separated by size. The average weight of the fruits by size was determined.

Vegetative growth of pepper plants was determined by measuring the dry biomass and the percentage of dry matter of the aerial part of the plant. Crop harvest index (HI, $\mathrm{g} \mathrm{g}^{-1}$ ) was calculated as the ratio between generative dry biomass and total shoot dry biomass. For this, whole plants (leave, stem and fruit), excluding roots, were collected from each experimental plot (six plants per repetition) at the end of the experiment and 20 fruits per experimental plot were also randomly selected in each harvest. The fresh samples were weighed and dried at $70{ }^{\circ} \mathrm{C}$ to constant weight and the dry weight was determined.

Productivity of water and nutrients was calculated. There are numerous authors who have defined the productivity of water or the efficiency of water use [37-42]. We define the productivity the following way:

1. Water productivity $(\mathrm{WP}) ; \mathrm{Y} / \mathrm{W}$.

2. Nitrogen productivity (NP); $\mathrm{Y} / \mathrm{Nc}$.

3. Phosphorus productivity (PP); $\mathrm{Y} / \mathrm{P}$.

4. Potassium productivity $(\mathrm{KP}) ; \mathrm{Y} / \mathrm{K}$.

5. Magnesium productivity $(\mathrm{MgP}) ; \mathrm{Y} / \mathrm{Mg}$.

where:

$\mathrm{Y}$ is fruit marketable yield $\left(\mathrm{kg} \mathrm{m}^{-2}\right)$.

$\mathrm{W}$ is water applied $\left(\mathrm{m}^{3} \mathrm{~m}^{-2}\right)$.

$\mathrm{N}$ is nitrogen applied $\left(\mathrm{kg} \mathrm{m}^{-2}\right)$.

$\mathrm{P}$ is phosphorus applied $\left(\mathrm{kg} \mathrm{m}^{-2}\right)$.

$\mathrm{P}$ is potassium applied $\left(\mathrm{kg} \mathrm{m}^{-2}\right)$.

Ca is calcium applied $\left(\mathrm{kg} \mathrm{m}^{-2}\right)$.

$\mathrm{Mg}$ is magnesium applied $\left(\mathrm{kg} \mathrm{m}^{-2}\right)$.

\subsection{Statistical Analysis}

An analysis of variance (ANOVA) was performed for a 2 by 2 factorial balanced incomplete block design with eight repetitions. To identify the significant factors (SMP and $\mathrm{G}$ ) and the interactions between the factors, a multifactorial ANOVA was performed. When the ANOVA was significant, an least significant difference LSD test $(p \leq 0.05)$ was performed to identify statistically significant differences between the means. To obtain a normal distribution, the percentage data were transformed with an inverse sign $\sqrt{ }$. The statistical software used was Statgraphics 18.

\section{Results}

\subsection{Climatic Parameters}

The average daily air temperature inside the greenhouses fluctuated throughout the growing cycle, being higher at the beginning of the cycle with average values close to $30^{\circ} \mathrm{C}$ and with minimum values in the winter months, the lowest recorded average being $12{ }^{\circ} \mathrm{C}$ (Figure 3a). During most of the growing cycle the average daily temperature was around $15^{\circ} \mathrm{C}$. It is noteworthy that in the two greenhouses $\left(G_{1}\right.$ and $\left.G_{2}\right)$ the air temperature was very similar (Figure $3 a)$. 
(a)

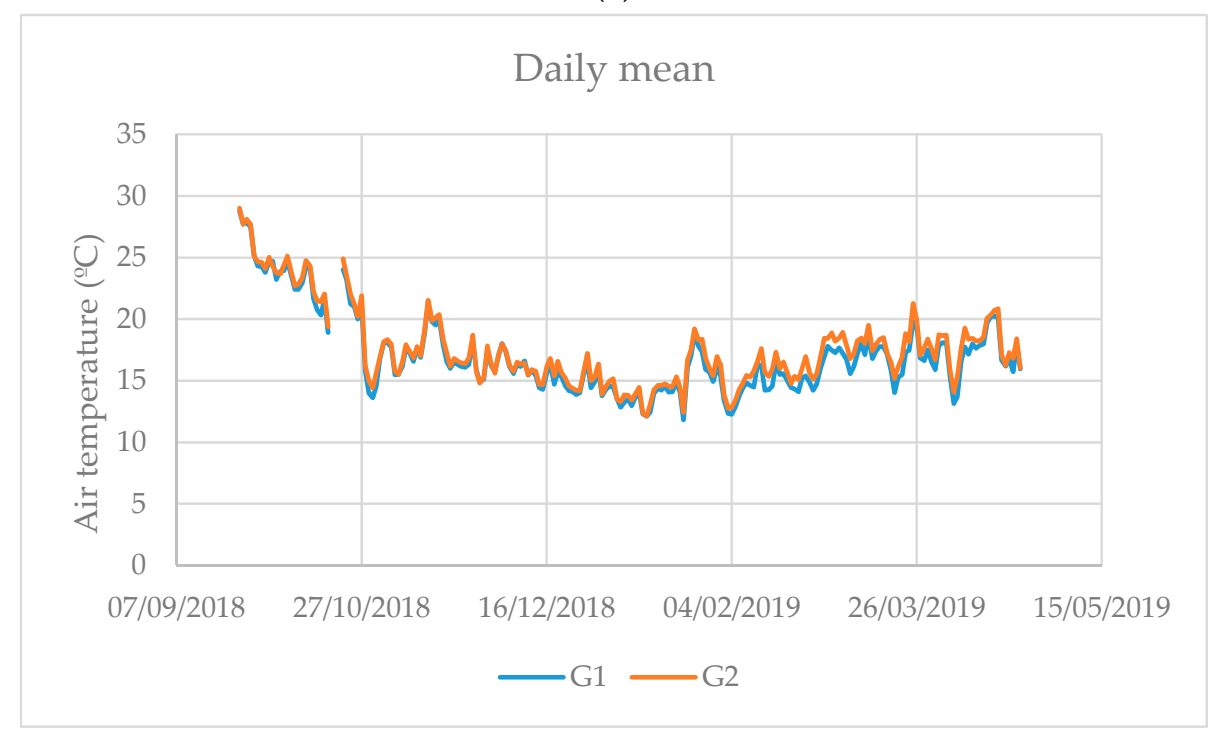

(b)

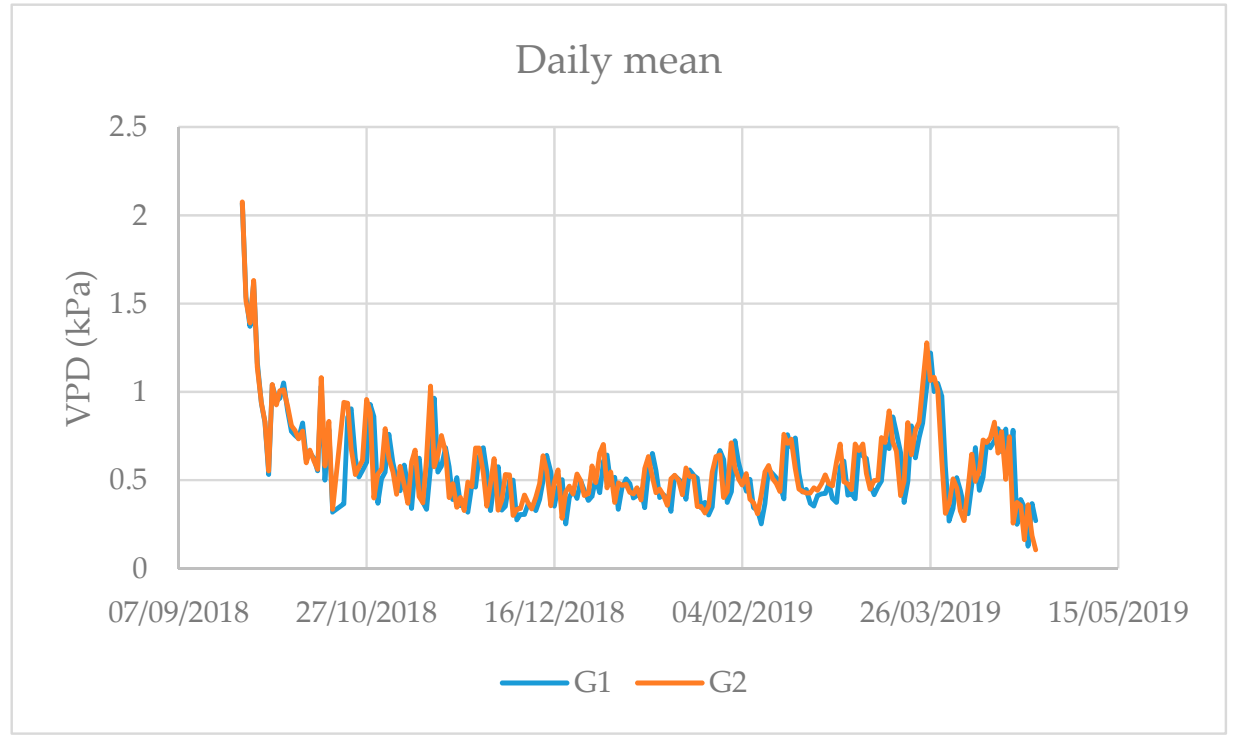

Figure 3. Daily mean air temperature (a) and daily mean air vapor pressure deficit (VPD) (b) inside of the two greenhouse during the growing seasons.

The daily mean VPD also showed fructifications throughout the crop cycle (Figure 3b). At the beginning of the cycle it was high, reaching values of $2 \mathrm{kPa}$ (September 24), although, during most of the growing cycle it was around $0.5 \mathrm{kPa}$. As with air temperature, the VPD it was similar in the two greenhouses (Figure $3 b$ ).

\subsection{Soil Matric Potential (SMP)}

The fertigation treatments began on 23 October 2018. Figure 4 shows the matric potential values of the soil for the established treatments $\left(\mathrm{SMP}_{-10}\right.$ and $\left.\mathrm{SMP}_{-20}\right)$ and for each greenhouse. The threshold values of soil matric potential established for each treatment were exactly the setpoints established for each treatment, since the activation of irrigation was established with the reading values of the tensiometers. 
(a)

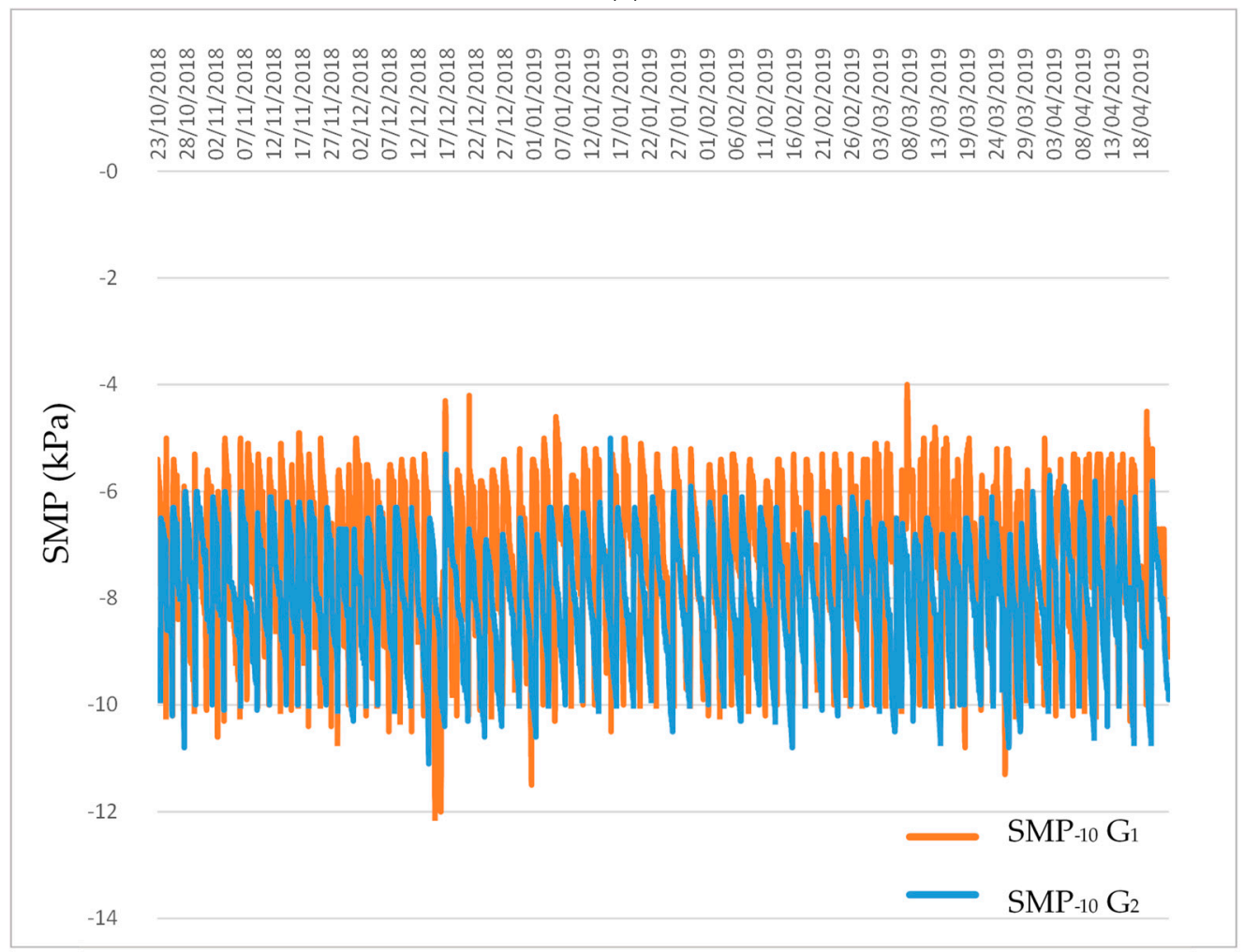

(b)

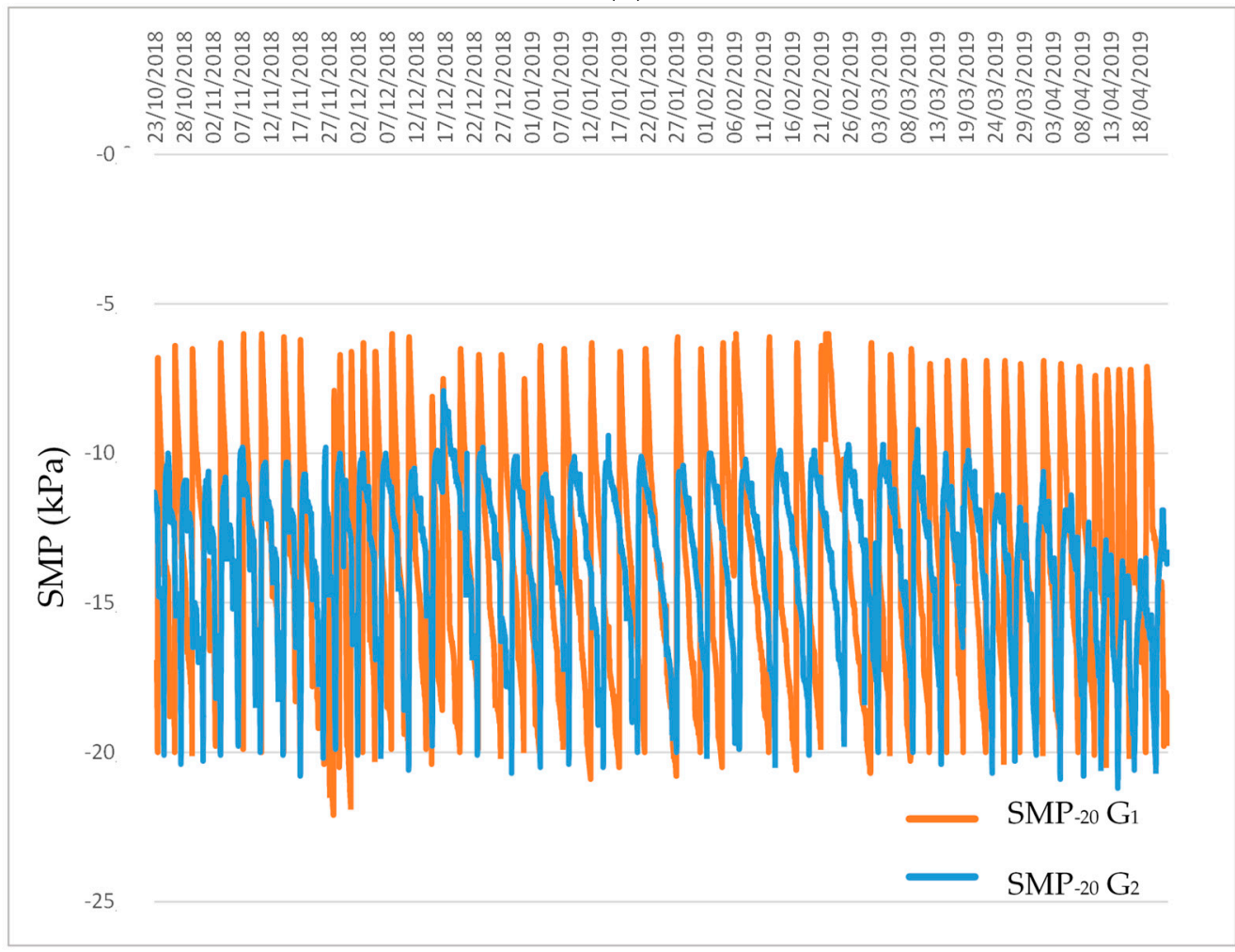

Figure 4. Soil matric potential variations for treatments in the growing seasons. Treatments $\mathrm{SMP}_{-10}$ $\mathrm{G}_{1}$ and $\mathrm{SMP}_{-10} \mathrm{G}_{2}$ (a) represent controlling soil matric potential thresholds of $-10 \mathrm{kPa}$ in the differents greenhouse studied, and treatments $S M P_{-20} G_{1}$ and $S_{M P}-20 G_{2}$ (b) represent controlling soil matric potential thresholds of $-20 \mathrm{kPa}$ in the differents greenhouse studied. 
Before starting the fertigation treatments, soil matric potential was similar for all treatments and was close to $-10 \mathrm{kPa}$.

Although the same amount of water was applied to each irrigation in both greenhouses, in greenhouse $\mathrm{G}_{1}$ the range of SMP was wider than in greenhouse $\mathrm{G}_{2}$. The SMP values for fertigation activation at $-10 \mathrm{kPa}$ were between -5 and $-10 \mathrm{kPa}$ for $\mathrm{G}_{1}$, however, they were between -6 and $-10 \mathrm{kPa}$ for $\mathrm{G}_{2}$. The same was registered with the SMP values for fertigation activation at $-20 \mathrm{kPa}$, registering a greater range (from -6 to $-20 \mathrm{kPa}$ ) in $\mathrm{G}_{1}$ and a smaller range (from -10 to $-20 \mathrm{kPa}$ ) in $\mathrm{G}_{2}$.

\subsection{Irrigation Water and Nutrients Applied and Drainage Volume}

Water and nutrients applied in each level and factor is shown in Table 3. The irrigation activation depending on the level of soil matric potential had an influence on the volume of water applied to the pepper crop. Activation of fertigation at $-10 \mathrm{kPa}$ increased the volume of water and applied nutrients by $28 \%$ (from 237 to $303 \mathrm{~L} \mathrm{~m}^{-2}$ ) (Table 3). The greenhouse also affected the volume of water and nutrients applied. $G_{1}$ applied $13 \%$ more water and nutrients than $\mathrm{G}_{2}$. There was no interaction between the factors studied (Table 3).

Table 3. Total water and nutrients applied and drainage volume.

\begin{tabular}{|c|c|c|c|c|c|c|c|c|}
\hline & & Water & $\mathbf{N}$ & $\mathbf{P}$ & $\mathbf{K}$ & $\mathrm{Ca}$ & Mg & Drainage \\
\hline & & $\mathrm{L} \mathrm{m}^{-2}$ & & & $\mathrm{~g} \mathrm{~m}^{-2}$ & & & $\mathrm{~L} \mathrm{~m}^{-2}$ \\
\hline \multirow[t]{3}{*}{ SMP } & & * & * & * & * & * & * & $\mathrm{ns}$ \\
\hline & -10 & 303.11 & 3.64 & 0.45 & 1.97 & 1.36 & 0.45 & 0.0 \\
\hline & -20 & 236.76 & 2.84 & 0.36 & 1.54 & 1.07 & 0.36 & 0.0 \\
\hline \multirow[t]{3}{*}{ G } & & $*$ & $*$ & $*$ & $*$ & $*$ & $*$ & ns \\
\hline & 1 & 286.49 & 3.44 & 0.43 & 1.86 & 1.29 & 0.43 & 0.0 \\
\hline & 2 & 253.39 & 3.04 & 0.38 & 1.65 & 1.14 & 0.38 & 0.0 \\
\hline \multicolumn{2}{|c|}{ Interaction } & ns & ns & ns & ns & ns & ns & ns \\
\hline
\end{tabular}

* significance for $p \leq 0.05 ; \mathrm{ns}$, no significance.

To calculate the ETc, the irrigation software PrHo v 2.0® 2008 was used and the climatic data corresponding to the average climatic year was the historical series of the Cajamar Foundation (https:/ / www.fundacioncajamar.es/es/comun/). The aforementioned software calculates the reference evapotranspiration (ETo) using a simplified version of the FAO (Food and Agriculture Organization of the United Nations)-radiation model [8] and adjusts the culture coefficient using the Kc-TTA (crop coefficient -accumulated thermal time) model [6]. For this cycle of greenhouse pepper cultivation, the ETc was $301 \mathrm{~L} \mathrm{~m}^{-2}$.

It is remarkable that for the SMP factor, the level $-10(-10 \mathrm{kPa})$ registered a water consumption very similar to the ETc calculated (303 vs. $301 \mathrm{~L} \mathrm{~m}^{-2}$ ).

No drainage was obtained in any of the treatments, regardless of the threshold of soil matric potential and greenhouse (Table 3). These results indicate that the volumes applied by the crop in the different treatments were not in excess at any moment of the cycle, achieving that $100 \%$ of the applied water stayed in the profile of the soil used by the roots of the crop.

\subsection{Yield}

The fertigation activation threshold had a significant effect on the total commercial production of pepper, the treatments that had a higher level of soil moisture in the soil (SMP -10$)$ obtained higher productions than those with a lower level of soil moisture (SMP-20). The average marketable yield in $\mathrm{SMP}_{-10}$ was $6.87 \mathrm{~kg} \mathrm{~m}^{-2}$ compared to $5.88 \mathrm{~kg} \mathrm{~m}^{-2}$ in SMP -20 (Table 4). When analyzing the marketable yield by size, it was found that these differences in total marketable yield were associated with a higher yield and number of fruits of size I in the $\mathrm{SMP}_{-10}$ level, showing no significant differences in yield and number of fruits of size II. The fruits of size I presented an average weight of 390 to $400 \mathrm{~g}$ and the fruits classified as size II an average weight of $200 \mathrm{~g}$, without significant differences between levels. Most 
of the marketable yield corresponded to fruits of size I, representing $91 \%$ for $\mathrm{SMP}_{-10}$ and $88 \%$ for $\mathrm{SMP}_{-20}$. Unmarketable fruits represented a very low percentage with respect to commercial production, being $4 \%$ for the $\mathrm{SMP}_{-10}$ level and $2.7 \%$ for the $\mathrm{SMP}_{-20}$ level with significant differences between them.

Table 4. Total marketable yield, marketable by sizes and unmarketable pepper yield.

\begin{tabular}{|c|c|c|c|c|c|c|c|c|c|}
\hline & & \multirow{3}{*}{$\begin{array}{c}\text { Total } \\
\text { Marketable } \\
\mathrm{kg} \mathrm{m}^{-2}\end{array}$} & \multicolumn{6}{|c|}{ Marketable by Size } & \multirow{3}{*}{$\begin{array}{c}\text { Unmarketable } \\
\%\end{array}$} \\
\hline & & & \multicolumn{3}{|c|}{ Size I (>250 g) } & \multicolumn{3}{|c|}{ Size II (<250 g) } & \\
\hline & & & $\mathrm{kg} \mathrm{m}^{-2}$ & Fruits $\mathbf{m}^{-2}$ & $\begin{array}{c}\text { Fruits Weight } \\
(\mathrm{kg})\end{array}$ & $\mathrm{kg} \mathrm{m}^{-2}$ & Fruits $\mathrm{m}^{-2}$ & $\begin{array}{c}\text { Fruits Weight } \\
(\mathrm{kg})\end{array}$ & \\
\hline \multirow[t]{3}{*}{ SMP } & & * & * & * & ns & ns & ns & ns & * \\
\hline & -10 & 6.87 & 6.18 & 15.73 & 0.39 & 0.69 & 3.50 & 0.20 & 4.0 \\
\hline & -20 & 5.89 & 5.25 & 13.07 & 0.40 & 0.63 & 3.20 & 0.20 & 2.7 \\
\hline \multirow[t]{3}{*}{ G } & & $*$ & $*$ & $*$ & ns & $\mathrm{ns}$ & $\mathrm{ns}$ & $\mathrm{ns}$ & $*$ \\
\hline & 1 & 6.72 & 6.07 & 15.43 & 0.40 & 0.64 & 3.37 & 0.19 & 4.61 \\
\hline & 2 & 6.04 & 5.36 & 13.38 & 0.40 & 0.68 & 3.33 & 0.20 & 2.09 \\
\hline \multicolumn{2}{|c|}{ Interaction } & ns & ns & ns & ns & ns & ns & ns & ns \\
\hline
\end{tabular}

* significance for $p \leq 0.05 ;$ ns, no significance.

The greenhouse factor also influenced marketable yield, $\mathrm{G}_{1}$ was more productive than $\mathrm{G}_{2}\left(6.72\right.$ vs. $\left.6.04 \mathrm{~kg} \mathrm{~m}^{-2}\right)$. The increase in total marketable yield was associated with a higher production and fruits number of size I. The average weight of the fruits within each size was not modified by the greenhouse factor. The percentage of unmarketable yield was higher in $G_{1}$, although it represented only $4.61 \%$ with respect to total yield.

No interaction between factors was registered.

The total marketable yield was very well correlated with fertigation volume applied (Figure 5) with a high determination coefficient $\left(\mathrm{R}^{2}=0.9798\right)$ and this relationship was also regressed as follows:

Fertigation volume $\left(\mathrm{L} \mathrm{m}^{-2}\right)=60.95 *$ marketable yield $\left(\mathrm{kg} \mathrm{m}^{-2}\right)-118.89$

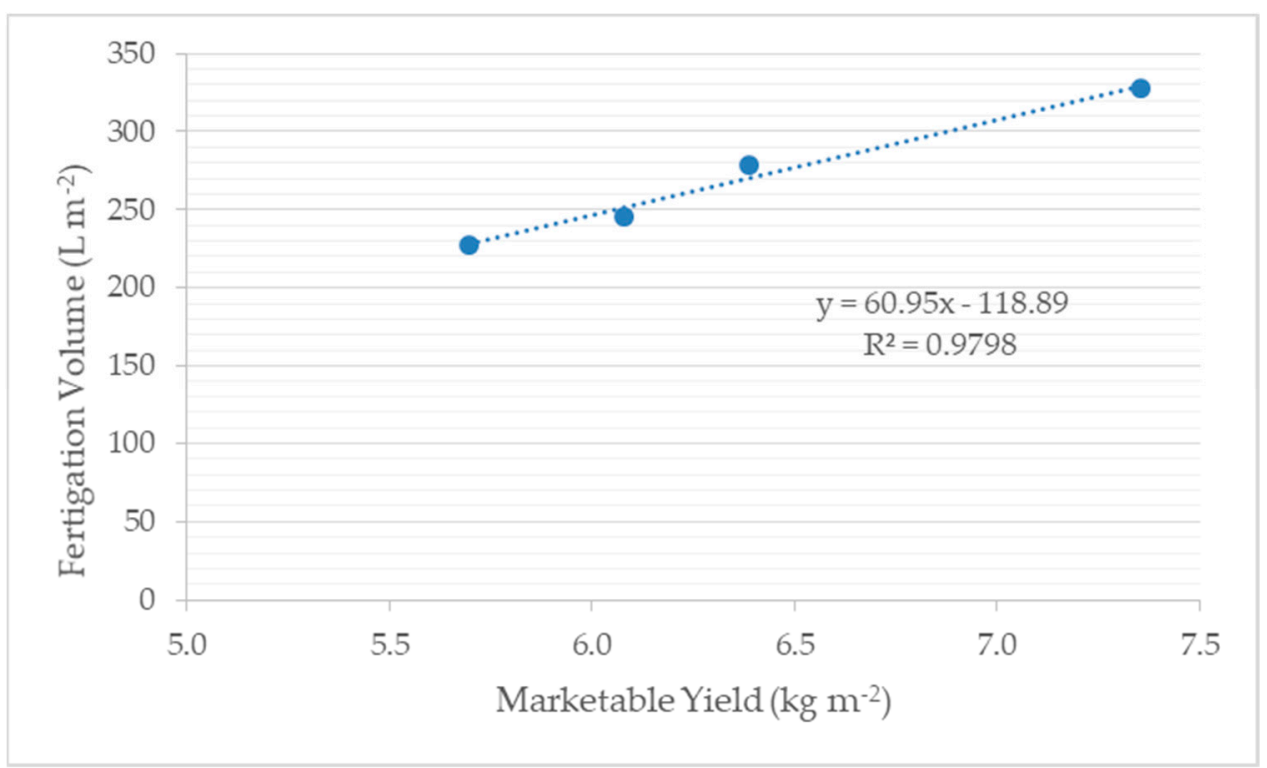

Figure 5. Linear relationship between total marketable yield and fertigation volume applied.

\subsection{Total Dry Biomass}

Dry matter content in plant tissue, shoot biomass (dry matter) and its partitioning at the end of the cycle are shown in Table 5. Vegetative growth of pepper plants was influenced by the threshold of soil matric potential established. Total shoot biomass was reduced with decreasing soil matric potential. This reduction was due to a statistically 
significant reduction in the biomass of stem, leaf and fruit registered at the $\mathrm{SMP}_{-20}$ level. The reduction in total dry biomass was estimated at $25 \%$ (Table 5). This reduction in biomass could be the main cause of the differences recorded in water consumption between the different treatments.

Table 5. Stem, leaf and fruit dry matter. Vegetative, generative and total shoot biomass, and crop harvest index (HI).

\begin{tabular}{|c|c|c|c|c|c|c|c|c|c|}
\hline & & \multicolumn{3}{|c|}{ Dry Matter Content (\%) } & \multicolumn{4}{|c|}{ Shoot Biomass ( $\mathrm{g} \mathrm{m}^{-2}$ ) } & \multirow[t]{3}{*}{$\mathrm{HI}\left(\mathrm{g} \mathrm{g}^{-1}\right)$} \\
\hline & & \multirow[b]{2}{*}{ Stem } & \multirow[b]{2}{*}{ Leaf } & \multirow[b]{2}{*}{ Fruit } & \multicolumn{2}{|c|}{ Vegetative } & \multirow{2}{*}{$\begin{array}{c}\text { Generative } \\
\text { Fruit }\end{array}$} & \multirow[t]{2}{*}{ Total } & \\
\hline & & & & & Stem & Leaf & & & \\
\hline SMP & & ns & ns & ns & * & * & * & * & ns \\
\hline & -10 & 20.7 & 17.2 & 9.3 & 220 & 170 & 664 & 1054 & 0.63 \\
\hline & -20 & 21.3 & 18.0 & 9.4 & 174 & 140 & 576 & 890 & 0.65 \\
\hline G & & ns & ns & ns & $*$ & $*$ & * & * & ns \\
\hline & 1 & 21.0 & 17.5 & 9.3 & 209 & 166 & 650 & 1025 & 0.63 \\
\hline & 2 & 21.0 & 17.7 & 9.4 & 184 & 144 & 590 & 918 & 0.64 \\
\hline Inter & & ns & ns & ns & ns & ns & ns & ns & ns \\
\hline
\end{tabular}

* significance for $p \leq 0.05$; ns, no significance.

All treatments recorded a similar HI (Table 5). This indicates that the relationship between the vegetative part (leaf + stem) and the generative part (fruit) did not vary as a function of the matric potential of the soil, and neither as a function of the greenhouse.

\subsection{Water and Nutrients Productivity}

Neither of the two factors studied (SMP and G) affected water and nutrient productivity by pepper crop (Table 6). The WP ranged between 23 and $25 \mathrm{~kg} \mathrm{~m}^{-3}$. The productivity of nutrients varied as a function of the nutrient, ranging the values for NP between 1.9 and $2.1 \mathrm{~kg} \mathrm{~g}^{-1}$, for PP between 15.3 and $16.7 \mathrm{~kg} \mathrm{~g}^{-1}$, for KP between 3.5 and $3.9 \mathrm{~kg} \mathrm{~g}^{-1}$, for CaP between 5.1 and $5.6 \mathrm{~kg} \mathrm{~g}^{-1}$ and for $\mathrm{MgP}$ between 15.3 and $16.7 \mathrm{~kg} \mathrm{~g}^{-1}$.

Table 6. Water productivity (WP) (kg of commercial fruit per $\mathrm{m}^{3}$ of water applied) and nutrients productivity ( $\mathrm{kg}$ of commercial fruit per kg nutrient applied). NP: Nitrogen productivity, PP: Phosphorus productivity; KP: Potassium productivity, CaP: Calcium productivity and MgP: Magnesium productivity.

\begin{tabular}{|c|c|c|c|c|c|c|c|}
\hline & & WP & NP & $\mathbf{P P}$ & $\mathbf{K P}$ & $\mathrm{CaP}$ & MgP \\
\hline & & $\left(\mathrm{kg} \mathrm{m}^{-3}\right)$ & & & $\operatorname{cg~}^{-1}$ & & \\
\hline \multirow[t]{3}{*}{ SMP } & & ns & ns & ns & ns & ns & ns \\
\hline & -10 & 22.87 & 1.91 & 15.25 & 3.52 & 5.08 & 15.25 \\
\hline & -20 & 24.76 & 2.09 & 16.73 & 3.86 & 5.58 & 16.73 \\
\hline \multirow[t]{3}{*}{ G } & & ns & ns & ns & ns & ns & ns \\
\hline & 1 & 23.40 & 1.98 & 15.82 & 3.65 & 5.27 & 15.82 \\
\hline & 2 & 24.23 & 2.02 & 16.15 & 3.73 & 5.38 & 16.15 \\
\hline Interaction & & ns & ns & ns & ns & ns & ns \\
\hline
\end{tabular}

ns, no significance.

\section{Discussion}

\subsection{Soil Matric Potential Effect}

To maintain a SMP closer to zero (higher level of soil moisture and therefore greater water availability) it is necessary to apply a greater volume of irrigation water, as collected in numerous investigations $[4,29,30,43-45]$ and it is corroborated with the results obtained in this experiment.

To maintain the SMP threshold at $-10 \mathrm{kPa}$ during the sweet pepper crop cycle, the total volume of irrigation water needed was $303 \mathrm{Lm}^{-2}$. This volume was very similar to 
the ETc estimated using the methodology proposed by Fernandez et al. [6] with average climate data.

However, to maintain the SMP threshold at $-20 \mathrm{kPa}$ throughout the cycle, the necessary volume was $22 \%$ lower $\left(237 \mathrm{Lm}^{-2}\right)$. By reducing the volume of water applied, the nutrients applied in fertigation were also proportionally reduced, factors which limited the yield of the crop under our growing conditions [46]. As there was no drainage and therefore no nutrient leachate with any of the soil matric potential thresholds studied, we can say that the volumes of water supplied were entirely used by the crop.

The greater availability of water and nutrients obtained when fertigation is activated at a SMP threshold of $-10 \mathrm{kPa}$ increased the yield and number of fruits of the sweet pepper crop with respect to the activation of fertigation at a SMP threshold of $-20 \mathrm{kPa}$, as a consequence of a greater yield and number of fruits of greater size. Different authors have studied the effect of soil matric potential on productivity in different crops and production systems [36-40]. Coinciding with what was observed in this experiment, numerous authors have observed a relationship between SMP and crop yield. The results obtained in this work coincide with those of other trials carried out on the same crop (sweet pepper) and under similar development conditions, in a greenhouse and soil with a layer of sand provided $[47,48]$. The results were also similar to those obtained in other greenhouse horticultural crops such as zucchini (also in soil with a surface layer of sand) $[4,49]$ confirming that an irrigation activation threshold closer to saturation increases fruit production. Even so, the magnitude of importance varies according to the crop, so that in previous trials carried out in zucchini crop [4] we determined that a modification in the threshold of the soil matric potential from -10 to $-25 \mathrm{kPa}$ produces a slight significant reduction in marketable yield, estimated at $10 \%$. However, in this experiment on sweet pepper cultivation, a smaller variation of the soil matric potential (from -10 to $-20 \mathrm{kPa}$ ) produced a greater decrease in commercial production ( $14 \%$, from $6.87 \mathrm{~kg} \mathrm{~m}^{-2}$ to $\left.5.88 \mathrm{~kg} \mathrm{~m}^{-2}\right)$.

Specifically, Létourneau et al. [30] managed to improve strawberry crop yields grown in the open field by $6.2 \%$ when they worked with a soil matric potential of $-15 \mathrm{kPa}$ instead of $-20 \mathrm{kPa}$. Similarly, for tomato crops grown in the open field, Zheng et al. [45] obtained a reduction in production between $23.0 \%$ and $27.7 \%$ depending on the season, by reducing the matric potential of the soil from $-10 \mathrm{kPa}$ to $-50 \mathrm{kPa}$ and Buttaro et al. [29] established that the greenhouse tomato irrigated at the potential of $-40 \mathrm{kPa}$ showed a $40 \%$ lower yield (mainly due to the smaller size of the fruit) compared to the plants watered at $-10 \mathrm{kPa}$.

As was observed in crop yield, the development of the plant was also affected by the irrigation activation SMP threshold, obtaining higher aerial dry biomass in the treatments in which $-10 \mathrm{kPa}$ was established compared with $-20 \mathrm{kPa}$. This higher dry biomass was associated with a higher production of fresh biomass, higher vegetative development, since the percentage of dry matter in the tissues was not altered by the SMP values studied. HI was high (between $63 \%$ and $65 \%$ ) and was not affected by the levels of SMP studied, conserving the proportion of fruit and vegetative part. Coinciding with numerous investigations $[4,29,43,44]$, deficit irrigation produces as a reduction in vegetative growth.

The irrigation activation threshold of $-10 \mathrm{kPa}$ maintained the productivity of water and nutrients in agronomic terms. Water productivity in agronomic terms was around $24 \mathrm{~kg}$ of commercial pepper fruit per $\mathrm{m} 3$ of applied fertigation, being similar to that obtained in previous trials under similar development conditions $[47,48]$. Numerous studies show how increasing the volume of water and nutrients applied reduces their productivity, although fruit production increases $[4,29,30,43,49]$. However, in this trial, productivity has been preserved and fruit production has increased, and it can be concluded that, under the trial development conditions, the $-10 \mathrm{kPa}$ treatment has been the best.

\subsection{Greenhouse Effect}

The greenhouse factor affected the volume of fertigation applied. Growing in the $\mathrm{G}_{1}$ greenhouse required $13 \%$ more fertigation than the $\mathrm{G}_{2}$ greenhouse. These differences between the greenhouses in the volume of fertigation demanded could be the consequence 
of different environmental conditions between greenhouses (caused by different ventilations) and of the different types of soil (different textures and moisture retention curves). Sánchez-Guerrero et al. [23] and Stanghellini et al. [24] found that within the greenhouse cultivation system there are several factors such as: Greenhouse structure, ventilation and soil type. that determine and modify the consumption of water and fertilizers by modifying the environmental conditions in which the crops develop and the level of development of said crop. However, in this trial, the results of the climatic parameters inside the greenhouse were similar in both greenhouses (Figure 3). Although the height of the greenhouses and the ventilation surface were different, neither the temperature nor the VPD were modified, so these differences in the consumption of fertigation volume must have been associated with the soil. The variation of the soil matric potential was different in each of the greenhouses (Figure 4), the soil of the greenhouse $\mathrm{G}_{1}$ showed more variation of SMP than the soil of $G_{2}$ with the same depth of applied water $\left(3 \mathrm{~L} \mathrm{~m}^{-2}\right.$ corresponding $30 \mathrm{~min}$ of irrigation time). The $\mathrm{G}_{1}$ soil presented lower levels of SMP after irrigation associated with the retention curve characteristic of each type of soil (Figure 4). The SMP values for fertigation activation at $-10 \mathrm{kPa}$ were between -5 and $-10 \mathrm{kPa}$ for $\mathrm{G}_{1}$, however, they were between -6 and $-10 \mathrm{kPa}$ for $\mathrm{G}_{2}$. The same was recorded with the SMP values for the activation of fertigation at $-20 \mathrm{kPa}$, registering a higher range ( -6 to $-20 \mathrm{kPa})$ in $\mathrm{G}_{1}$ and a lower range $(-10$ to $-20 \mathrm{kPa})$ in $\mathrm{G}_{2}$.

The greenhouse also affected the commercial yield, the greenhouse $\mathrm{G}_{1}$ had $11 \%$ more production than the greenhouse $\mathrm{G}_{2}\left(6.7 \mathrm{vs} .6 .0 \mathrm{~kg} \mathrm{~m}^{-2}\right)$. This percentage was similar to the increase in fertigation demanded in this greenhouse. The higher demand for fertigation carried out in the $G_{1}$ greenhouse was possibly associated with the greater development of the crop in this greenhouse, not only the commercial production was higher, but also the dry biomass of the crop (of leaves, stem and fruit) was higher associated with higher fresh biomass, since the percentage of dry matter in the tissue was the same for the cultivation in the two greenhouses studied. This higher growth was possibly associated with the more favorable level of average matric potential recorded in the soil of the $\mathrm{G}_{1}$ greenhouse, which has already been commented on previously, since the climatic conditions recorded in the greenhouses were similar. The higher fruit production and crop development when irrigation is activated at a matric potential closer to zero has been widely corroborated by different authors and in different crops $[4,29,30,45,47,48]$. The highlight from the results obtained in this experiment was that no only SMP threshold at which irrigation was activated had an influence, the SMP reached after finishing the irrigation also had an influence on the production and growth of the crop.

The two greenhouses registered high water and nutrient productivities without significant differences between them. Water productivity in agronomic terms was around $24 \mathrm{~kg}$ of commercial pepper fruit per $\mathrm{m}^{3}$ of fertigation applied for the two greenhouses, being similar to that obtained in previous trials under similar development conditions $[46,47]$.

\section{Conclusions}

The results obtained in this work showed the great importance of establishing an optimum level of SMP threshold value to automate fertigation with electrotensiometers in greenhouse pepper crops. Under the development conditions of the experiment, the activation threshold of $-10 \mathrm{kPa}$ increased fruit production as well as the biomass and conserved water and nutrients productivity with respect to the activation threshold of $-20 \mathrm{kPa}$ in both greenhouses.

The greenhouse factor also had a significant influence on fruit production, the crop in greenhouse $\mathrm{G}_{1}$ obtained higher yields and vegetative development, also requiring a greater volume of fertigation than the crop developed in the greenhouse $\mathrm{G}_{2}$ for the same activation threshold. This better response was associated with a more favorable average matric potential recorded in the soil of this greenhouse, since the matric potential threshold after irrigation was closer to zero. Therefore, it was shown that not only the SMP threshold used by fertigation activation had an influence, but also the lowest SMP threshold obtained 
after fertigation, confirming that it is necessary to establish depth irrigation that achieve a SMP closer to zero to achieve increased fruit yield and crop growth. Therefore, it is essential to know the soil retention curve to adapt the irrigation endowment and reach a potential close to zero without producing losses due to deep filtration (drainage).

The automation of fertigation with electrotensiometers allowed applying the volume of fertigation demanded by the crop, which was different according to the soil conditions of each greenhouse, and was also different depending on the threshold value of the soil matric potential established for activation and also allowed to eliminate water losses by drainage and therefore the leaching of nutrients.

Author Contributions: Data curation, J.I.C., G.C. and F.A.; Formal analysis, J.I.C. and F.A.; Funding acquisition, R.B. and J.G.L.; Investigation, J.I.C., R.B., J.G.L. and F.A.; Methodology, J.I.C., R.B., J.G.L. and F.A.; Project administration, R.B. and J.G.L.; Resources, R.B. and J.G.L.; Supervision, R.B., J.I.C.; Validation, J.I.C.; Writing—original draft, J.I.C., R.B. and F.A.; Writing—review \& editing, J.I.C., R.B. and F.A. All authors have read and agreed to the published version of the manuscript.

Funding: This research was funded by European Regional Development Fund (ERDF), grand number A1122062U0 and the Agricultural Research and Training Institute of Andalusia (IFAPA), under projects: Technological Transfer for an Irrigation Sustainable. SAR, with code PP.TRA.TRA2019.006 and "Investigación, ensayo, publicación y transferencia de las directrices de manejo para la gestión conjunta de recursos hídricos convencionales y agua de mar desalada para riego en la comarca de Poniente", with code PP.PEI.IDF201601.12. The APC was funded by IFAPA.

Institutional Review Board Statement: Not applicable.

Informed Consent Statement: Not applicable.

Conflicts of Interest: The authors declare no conflict of interest.

Abbreviations
The following abbreviations are used in this manuscript:
$\begin{array}{ll}\text { SMP } & \text { Soil Matric Potential } \\ \text { G } & \text { Greenhouse } \\ \text { SWCC } & \text { Soil-Water Characteristic Curves } \\ \text { VPD } & \text { Vapor pressure deficit } \\ \text { WP } & \text { Water Productivity } \\ \text { NP } & \text { Nitrogen Productivity } \\ \text { PP } & \text { Phosphorus Productivity } \\ \text { KP } & \text { Potassium Productivity } \\ \text { CaP } & \text { Calcium Productivity } \\ \text { MgP } & \text { Magnesium Productivity } \\ \text { HI } & \text { Harvest Index } \\ \text { ETc } & \text { Evapotranspiration of crop }\end{array}$

\section{References}

1. UNESDOC. Digital Library. Available online: https:/ / unesdoc.unesco.org/ark:/48223/pf0000372985.locale=en (accessed on 15 September 2020).

2. $\quad$ UNESCO. The Agenda 21 World Water Development Report 3: Water in a Changing World; World Water Assessment Programme; UNESCO: Paris, France, 2009.

3. Evans, R.G. Microirrigacion; 24106 North Bunn Roas Prosser; Washington State University, Irrigated Agriculture Research and Extension Center: Washington, DC, USA, 2002.

4. Contreras, J.I.; Alonso, F.; Cánovas, G.; Baeza, R. Irrigation management of greenhouse zucchini with different soil matric potential level. Agronomic and environmental effects. Agric. Water Manag. 2017, 183, 26-34. [CrossRef]

5. Garcia-Caparros, P.; Contreras, J.I.; Baeza, R.; Segura, M.L.; Lao, M.T. Integral management of irrigation water in intensive horticultural systems of Almería. Sustainability 2017, 9, 2271. [CrossRef]

6. $\quad$ Fernández, M.D.; Orgaz, F.; Fereres, E.; López, J.C.; Céspedes, A.; Pérez, J.; Bonachela, S.; Gallardo, M. Programación del Riego de Cultivos Hortícolas bajo Invernadero en el Sudeste Español; Cajamar (Caja Rural Intermediterránea): Almería, Spain, 2001.

7. Gavilán, P.; Estévez, J.; Berengena, J. Comparison of standardized reference evapotranspiration equations in Southern Spain. J. Irrig. Drain. E 2008, 134, 1-12. [CrossRef] 
8. Fernández, M.D.; Bonachela, S.; Orgaz, F.; Thompson, R.; López, J.C.; Granados, M.R.; Gallardo, M.; Fereres, E. Measurement and estimation of plastic greenhouse reference evapotranspiration in a Mediterranean climate. Irrig. Sci. 2010, 28, 497-509. [CrossRef]

9. González-Esquiva, J.M.; Oates, M.J.; García-Mateos, G.; Moros-Valle, B.; Molina-Martínez, J.M.; Ruiz-Canales, A. Development of a visual monitoring system for water balance estimation of horticultural crops using low cost cameras. Comput. Electron. Agric. 2017, 141, 15-26. [CrossRef]

10. Camacho, F.F.; Fernández, E. Manual Práctico de Fertirrigación en Riego por Goteo; Ediciones Agrotécnicas S.L.: Madrid, Spain, 2008.

11. Segura, M.L.; Contreras, J.I.; Plaza, B.M.; Lao, M.T. Assessment of the Nitrogen and Potassium Fertilizer in Green Bean Irrigated with Disinfected Urban Wastewater. Commun. Soil Sci. Plant Anal. 2012, 43, 426-433. [CrossRef]

12. Contreras, J.I.; López, J.G.; Lao, M.T.; Eymar, E.; Segura, M.L. Dry-Matter Allocation and Nutrient Uptake Dynamic in Pepper Plant Irrigated with Recycled Water by Different Nitrogen and Potassium Rate. Commun. Soil Sci. Plant Anal. 2013, 44, 758-766. [CrossRef]

13. Contreras, J.I.; Cánovas, G.; Baeza, R. Aplicación en fondo de fertilizantes organominerales como alternativa a la fertirrigación convencional en cultivos hortícolas: II. Efecto sobre la dinámica de producción de frutos y nutrientes en suelo. Actas Hortic. 2014, 66, 59-64.

14. Segura, M.L.; Contreras, J.I. Efecto de la dosis NPK y salinidad del agua sobre los rendimientos y absorción de nutrientes del cultivo de tomate bajo invernadero. Actas Hortic. 2014, 66, 72-77.

15. Padilla, F.M.; Gallardo, M.; Peña-Fleitas, M.T.; De Souza, R.; Thompson, R.B. Proximal Optical Sensors for Nitrogen Management of Vegetable Crops: A Review. Sensors 2018, 18, 2083. [CrossRef]

16. Padilla, F.M.; Peña-Fleitas, T.; Gallardo, M.; Thompson, R.B. Evaluation of optical sensor measurements of canopy reflectance and of leaf flavonols and chlorophyll contents to assess crop nitrogen status of muskmelon. Eur. J. Agron. 2014, 58, 39-52. [CrossRef]

17. Martín, E.; Fernández, M.F. Seguimiento de los niveles de $\mathrm{NO}_{3}{ }^{-}$de la solución de suelo obtenida en profundidad mediante sondas de succión tipo Rhizon: Resultados preliminares. Actas Hortic. 2014, 66, 154-158.

18. Llanderal, A.; García-Caparrós, P.; Contreras, J.I.; Segura, M.L.; Lao, M.T. Spatio-temporal variations in nutrient concentration in soil solution under greenhouse tomato. J. Plant Nutr. 2019, 42, 842-852. [CrossRef]

19. Giménez, C.; Gallardo, M.; Martínez-Gaitán, C.; Stöckle, C.O.; Thompson, R.B.; Granados, M.R. VegSyst, a simulation model of daily crop growth, nitrogen uptake and evapotranspiration for pepper crops for use in an on-farm decision support system. Irrig. Sci. 2013, 31, 465-477. [CrossRef]

20. Gallardo, M.; Thompson, R.B.; Giménez, C.; Padilla, F.M.; Stöckle, C.O. Prototype decision support system based on the VegSyst simulation model to calculate crop $\mathrm{N}$ and water requirements for tomato under plastic cover. Irrig. Sci. 2014, 32, 237-253. [CrossRef]

21. Stanghellini, C. Horticultural production in greenhouses: Efficient use of water. Acta Hortic. 2014, 1034, 25-32. [CrossRef]

22. Graamans, L.; Baeza, E.; Van Den Dobbelsteen, A.; Tsafaras, I.; Stanghellini, C. Plant factories versus greenhouses: Comparison of resource use efficiency. Agric. Syst. 2018, 160, 31-43. [CrossRef]

23. Sánchez-Guerrero, M.C.; Lorenzo, P.; Medrano, E.; Baille, A.; Castilla, N. Effects of EC-based irrigation scheduling and CO 2 enrichment on water use efficiency of a greenhouse cucumber crop. Agric. Water Manag. 2009, 96, 429-436. [CrossRef]

24. Stanghellini, C.; Dai, J.; Kempkes, F. Effect of near-infrared-radiation reflective screen materials on ventilation requirement, crop transpiration and water use efficiency of a greenhouse rose crop. Biosyst. Eng. 2011, 110, 261-271. [CrossRef]

25. Adhikari, R.; Bristow, K.L.; Casey, P.S.; Freischmidt, G.; Hornbuckle, J.W.; Adhikari, B. Preformed and sprayable polymeric mulch film to improve agricultural water use efficiency. Agric. Water Manag. 2016, 169, 1-13. [CrossRef]

26. Ropokis, A.; Ntatsi, G.; Kittas, C.; Katsoulas, N.; Savvas, D. Effects of Temperature and Grafting on Yield, Nutrient Uptake, and Water Use Efficiency of a Hydroponic Sweet Pepper Crop. Agronomy 2019, 9, 110. [CrossRef]

27. Hanson, B.R.; Orloff, S.; Peters, D. Monitoring soil moisture helps refine irrigation management. Calif. Agric. 2000, 54, 38-42. [CrossRef]

28. Thompson, R.B.; Martínez-Gaitan, C.; Gallardo, M.; Giménez, C.; Fernández, M.D. Identification of irrigation and N management practices that contribute to nitrate leaching loss from an intensive vegetable production system by use of a comprehensive survey. Agric. Water Manag. 2007, 89, 261-274. [CrossRef]

29. Buttaro, D.; Santamaria, P.; Signore, A.; Cantore, V.; Boari, F.; Montesano, F.F.; Parente, A. Irrigation Management of Greenhouse Tomato and Cucumber Using Tensiometer: Effects on Yield, Quality and Water Use. Agric. Agric. Sci. Procedia 2015, 4, 440-444. [CrossRef]

30. Létourneau, G.; Caron, J.; Anderson, L.; Cormier, J. Matric potential-based irrigation management of field-grown strawberry: Effects on yield and water use efficiency. Agric. Water Manag. 2015, 161, 102-113. [CrossRef]

31. Observatorio de Precios y Mercados. Junta de Andalucia. Datos Basicos de Producto de Pimiento. Campaña 2018/19. Available online: https: / / www.juntadeandalucia.es / agriculturaypesca / observatorio/ servlet/ FrontController?action=List\&table=1111 $3 \&$ subsector $=20 \&$ page $=1 \&$ ec $=$ default (accessed on 15 September 2020).

32. Contreras, J.I.; Martín, F.; Zapata, A.J.; López, J.G.; Baeza, R. Caracterización de suelos enarenados para la producción de pimiento en invernadero en la comarca del Campo de Dalías (Almería). In Proceedings of the XXXII Congreso Nacional de Riegos, Madrid, Spain, 10-12 June 2014; pp. 1-8.

33. Alonso, F.; Contreras, J.I.; Cánovas, G.; Gavilán, P.; Baeza, R. Gestión del riego automatizado con tensiómetros en pimiento cultivado en invernadero. Actas Port. Hortic. 2020, 30, 145-152. 
34. Bouyoucos, G.J. Hydrometer method improved for making particle size analyses of soils. Agron. J. 1962, 54, 464-465. [CrossRef]

35. Black, C.A. Methods of Soils Analysis, Part II: Chemical and Microbiological Properties; Soil Science Society of America: Madison, WI, USA, 1965.

36. Van Genuchten, M.T. A closed-form equation for predicting the hydraulic conductivity of unsaturated soils. Soil Sci. Soc. Am. J. 1980, 44, 892-898. [CrossRef]

37. Kang, S.; Zhang, J. Controlled alternate partial root-zone irrigation: Its physiological consequences and impact on water use efficiency. J. Exp. Bot. 2004, 55, 2437-2446. [CrossRef]

38. Wang, D.; Kang, Y.; Wan, S. Effect of soil matric potential on tomato yield and water use under drip irrigation condition. Agric. Water Manag. 2007, 87, 180-186. [CrossRef]

39. Fageria, N.K.; Baligar, V.C. Enhancing nitrogen use efficiency in crop plants. Adv. Agron. 2005, 88, 97-185.

40. Van Eerd, L.L. Evaluation of different nitrogen use efficiency indices using field-grown green bell peppers (Capsicum annuum L.). Can. J. Plant Sci. 2007, 87, 565-569.

41. Yasuor, H.; Ben-Gal, A.; Yermiyahu, U.; Beit-Yannai, E.; Cohen, S. Nitrogen management of greenhouse pepper production: Agronomic, nutritional, and environmental implications. HortScience 2013, 48, 1241-1249. [CrossRef]

42. Molden, D.; Oweis, T.; Steduto, P.; Bindraban, P.; Hanjra, M.A.; Kijne, J. Improving agricultural water productivity: Between optimism and caution. Agric. Water Manag. 2010, 97, 528-535. [CrossRef]

43. Liu, H.; Yang, H.; Zheng, J.; Jia, D.; Wang, J.; Li, Y.; Huang, G. Irrigation scheduling strategies based on soil matric potential on yield and fruit quality of mulched-drip irrigated chili pepper in Northwest China. Agric. Water Manag. 2012, 115, $232-241$. [CrossRef]

44. Jia, J.; Kang, Y.; Wan, S. Effect of soil matric potential on wolfberry (Lycium barbarbum L.) yield, evapotranspiration and water use efficiency under drip irrigation. Afr. J. Agric. Res. 2013, 8, 5455-5463.

45. Zheng, J.; Huang, G.; Jia, D.; Wang, J.; Mota, M.; Pereira, L.S.; Huang, Q.; Liu, H. Responses of drip irrigated tomato (Solanum lycopersicum L.) yield, quality and water productivity to various soil matric potential thresholds in an arid region of Northwest China. Agric. Water Manag. 2013, 129, 181-193. [CrossRef]

46. Contreras, J.I.; Eymar, E.; Lopez, J.G.; Lao, M.T.; Segura, M.L. Influences of Nitrogen and Potassium Fertigation on Nutrient Uptake, Production, and Quality of Pepper Irrigated with Disinfected Urban Wastewater. Commun. Soil Sci. Plant Anal. 2013, 44, 767-775. [CrossRef]

47. Alonso López, F.; López Segura, J.G.; Contreras París, J.I.; Cánovas Fernández, G.; Baeza Cano, R. Uso de electrotensiómetros para mejorar el manejo del riego en suelo en cultivos hortícolas intensivos. In Proceedings of the XLIX Seminario de Técnicos y Especialistas en Horticultura, Toledo, Spain, 9-12 September 2019.

48. Alonso, F.; Baeza, R.; Cánovas, G.; Contreras, J.I. Respuesta agronómica del cultivo de pimiento bajo invernadero a diferentes umbrales de potencial matricial del suelo. In Proceedings of the XLVIII Seminario de Técnicos y Especialistas en Horticultura, Muriedas, Spain, 11-14 June 2018.

49. Contreras, J.I.; Baeza, R.; Alonso, F.; Cánovas, G.; Gavilán, P.; Lozano, D. Effect of Distribution Uniformity and Fertigation Volume on the Bio-Productivity of the Greenhouse Zucchini Crop. Water 2020, 12, 2183. [CrossRef] 